\title{
Perbedaan Hasil Belajar Bahasa Indonesia Melalui Penerapan Metode Inquiry Dengan VCD Siswa Kelas VII Madrasah Tsanawiyah Negeri Lappariaja Kabupaten Bone
}

\author{
Suhardiman \\ Fakultas Keguruan dan Ilmu Pendidikan, Universitas Muhammadiyah Bone \\ Email: suhardimanbone@gmail.com
}

\begin{abstract}
Abstrak. Jenis penelitian ini adalah penelitian deskriptif kuantitatif dalam bentuk eksperimen yaitu penelitian yang bersifat langsung dilapangan untuk mengetahui perbandingan anatara variable X dan variabel Y, penelitian ini dilakukan di MTs Negeri Lappariaja yang tepatnya di Kelurahan Patangkai Kecamatan Lappariaja Kabupaten Bone Variabel penelitian ini terdiri dari dua macam variabel yaitu variabel bebas dan variabel terikat. Variabel bebas yang dimaksud adalah hasil belajar Bahasa Indonesia yang menggunakan metode inquiry dengan media VCD yang digunakan dalam mata pelajaran Bahasa Indonesia berada pada kategori sangat tinggi yaitu rata-rata 16,7 dan variabel terikat yang dimaksud adalah hasil belajar Bahasa Indonesia yang tidak menggunakan metode inquiry dengan media VCD berada pada kategori tinggi dengan skor 13,8 Hasil belajar siswa yang menerapkan metode hasil belajar Bahasa Indonesia yang menggunakan metode inquiry dengan media VCD dan tidak menggunakan metode inquiry dengan media VCD, ada perbedaan yaitu nilai t hitung 4,20 pada taraf signifikan $5 \%$ pada $t$ tabel $=2,020$.
\end{abstract}

\section{Kata Kunci: Metode Inquiri. Media VCD. Hasil Belajar}

\section{PENDAHULUAN}

Pendidikan mengembang suatu misi yang teramat penting yaitu membentuk manusia seutuhnya yang memiliki semangat kebangsaan cinta tanah air dan mampu mengisi partisipasi dalam pembangunan. Dalam era globalisasi ini semakin dirasakan betapa pentingnya pengembangan pendidikan, hal ini disebabkan karena banyaknya teknologi yang bermunculan atau pesatnya peradaban, manusia tetap lebih banyak disebabkan oleh bangsa Indonesia yaitu mewujudkan masyarakat modern yang berkepribadian yang adil dan makmur berdasarkan pancasila dan UUD. 1945

Dalam suatu proses belajar mengajar, dua unsur yang amat penting adalah metode mengajar dan media pengajaran. Kedua aspek ini saling berkaitan. Pemilihan salah satu metode mengajar tertentu akan mempengaruhi jenis media

pengajar yang sesuai, meskipun masih ada berbagai aspek lain yang harus diperhatikan dalam memilih media, antara lain tujuan pengajaran, jenis tugas, dan respon yang diharapkan siswa kuasai setelah pengajaran berlangsung, dan konteks pembelajaran termasuk karakteristik siswa. Meskipun demikian, dapat dikatakan bahwa salah satu fungsi utama media pengajaran adalah sebagai alat bantu mengajar yang turut mempengaruhi iklim, kondisi, dan lingkungan belajar yang ditata dan diciptakan oleh guru.

Media pengajaran membawa dan membangkitkan rasa senang dan gembira bagi siswa dan memperbarui semangat mereka membantu memantapkan pengetahuan pada benak para siswa serta menghidupkan pelajaran.

Media pelajaran, menurut kemp dan Daytori, dapat memenuhi tiga fungsi utama apabila media itu digunakan untuk perorangan, kelompok, atau kelompok pendengar yang besar jumlahnya, yaitu (1) memotivasi minat atau tindakan, (2) menyajikan informasi, dan (3) memberi instruksi. Untuk memenuhi fungsi motivasi, media pengajaran dapat direalisasikan dengan teknik drama atau hiburan. Hasil yang diharapkan adalah melahirkan minat dan merangsang para siswa atau pendengar untuk bertindak (turut memikul tanggung jawab, melayani secara sukarela, atau memberikan 
sumbangan material). Pencapaian tujuan ini akan mempengaruhi sikap, nilai , dan emosi.

Dalam proses belajar mengajar guru harus mempunyai kemampuan mengajar secara profesional dan terampil dalam menggunakan metode dan media yang tepat dalam proses belajar mengajar. Seorang guru harus menguasai materi yang akan disampaikan dan juga harus pandai menciptakan situasi dan kondisi belajar mengajar yang menarik. Demikian juga peserta didik harus memiliki kemauan dan kemampuan belajar yang tinggi serta harus berperan aktif dalam mengikuti proses belajar mengajar sehingga menjadi pribasi yang berkualitas.

Perkembangan ilmu pengetahuan dan teknologi (IPTEK) telah membawa perubahan yang sangat signifikan terhadap berbagai dimensi kehidupan manusia, baik dalam bidang Indonesia, sosial, budaya maupun pendidikan. Oleh karena itu agar pendidikan tidak tertinggal dari perkembangan ilmu pengetahuan dan teknologi perlu adanya penyesuaian-penyesuaian, terutama yang berkaitan dengan faktor-faktor pembelajaran di sekolah. Salah satu faktor tersebut adalah media pembelajaran yang perlu dipelajari dan dikuasai oleh guru, sehingga mereka dapat menyampaikan mata pelajaran kepada siswa secara baik dan mudah dipahami.

Dalam proses belajar mengajar di kelas hanya mneggunakan metode ceramah dan guru sebagai satu-satunya sumber belajar tanpa adanya media, maka komunikasi antara guru dan siswa tidak akan berjalan secara lancar. Hal ini terkait dengan permasalahan dalam proses belajar mengajar. Permasalahan yang dihadapi suasana kelas ramai, penjelasan guru membosankan, siswa kesulitan memahami pesan-pesan verbal, materi cenderung bersifat umum, dan kadang-kadang penyampaian guru terlalu cepat.

Sering kita jumpai banyak siswa merasa enggan menerima pelajaran dari seorang guru, karena merasa bosan. Dan tidak sedikit siswa mengeluh dengan mata pelajaran Indonesia, mereka merasa bahwa ilmu Indonesia merupakan pelajaran yang sangat sulit dan tidak disukai, karena pelajaran
Indonesia tidak hanya menghitung dan menghafal, tetapi harus faham dengan sesuatu yang dipelajari.

Penerapan metode inquiry dengan media VCD dilaksanakan di kelas VII Madrasah Tsanawiyah Negeri Lappariaja hal ini menjadi pertimbangan karena terdapat masalah yang berhubungan dengan rendahnya prestasi siswa pada mata pelajaran Indonesia sesuai dengan karakteristik tentang penerapan metode inquiry dengan media VCD belum pernah dilakukan di sekolah tersebut. Hal itulah merupakan dasar penelitian dan pertimbangan, sehingga menurut penulis merupakan suatu yang menarik dan pantas untuk diteliti

Proses belajar Pembelajaran seharusnya melibatkan peran siswa dalam menggali potensi belajar siswa dengan cara menggunakan metode inquiry dengan media VCD. Karena metode inquiry dengan media VCD sebagai perantara penyampai pesan untuk dikembangkan dan didayagunakan seoptimal mungkin. Karena metode dengan media meruapakan wadah yang dapat menyalurkan pesan yang oleh sumber pesan atau pemberi pesan ingin diteruskan atau disampaikan kepada penerima pesan. Dalam penyampaian pesan pembelajaran, guru tentunya menginginkan agar pesan yang disampaikan dapat diterima dengan jelas, mudah dimengerti siswa, konkrit dan tahan lama dalam ingatan siswa.

Berdasarkan latar belakang di atas, maka hal itu menjadi suatu alasan yang sangat tepat bagi penulis untuk mengangkat permasalahan tersebut dalam sebuah tulisan skrBahasai yang berjudul "perbedaan hasil belajar Bahasa Indonesia yang menggunakan metode inquiry dengan media VCD dan tidak menggunakan metode inquiry dengan media VCD siswa kelas VII Madrasah Tsanawiyah Negeri Lappariaja Kecamatan Lappariaja Kabupaten Bone.

Berdasarkan latar belakang di atas, penulis merumuskan masalah yaitu apakah ada perbedaan hasil belajar Bahasa Indonesia melalui penerapan metode inquiry dengan VCD siswa kelas VII Madrasah Tsanawiyah 


\section{Negeri Lappariaja Kecamatan Lappariaja Kabupaten Bone. \\ Mengacu pada rumusan masalah di atas, maka penelitian ini bertujuan untuk mengetahui perbedaan hasil belajar Bahasa Indonesia melalui penerapan metode inquiry dengan VCD siswa kelas VII Madrasah Tsanawiyah Negeri Lappariaja Kecamatan Lappariaja Kabupaten Bone.}

\section{KAJIAN LITERATUR}

Hasil belajar adalah serangkaian kalimat yang terdiri dari dua kata, yaitu hasil dan belajar, dimana kedua kata tersebut saling berkaitan dan diantara keduanya mempunyai pengertian yang berbeda. Oleh karena itu, sebelum mengulas lebih dalam tentang prestasi belajar, terlebih dahulu kita telusuri kata tersebut satu persatu untuk mengetahui apa pengertian prestasi belajar itu. Menurut Djamarah prestasi belajar adalah hasil dari suatu kegiatan yang telah dikerjakan, diciptakan, baik secara individu maupun kelompok.

Menurut Gagne belajar adalah seperangkat proses kognitif yang merubah sifat stimulasi lingkungan, melewati pengolahan tentang informasi menjadi kapabilitas baru. Belajar merupakan kegiatan yang kompleks dan hasil dari belajar itu dapat berupa kapasitas baru. Artinya, sikap dan nilai sebagai akibat dari proses belajar tersebut. Timbulnya kapabilitas tersebut adalah stimulasi yang berasal dari lingkungan dan proses kognitif yang dilakukan oleh orang yang belajar.

Menurut Hilgard dan Bower belajar berhubungan dengan tingkah laku berulangulang dalam situasi tertentu yang disebabkan oleh pengalamannya yang berulang-ulang dalam situasi tertentu, dimana perubahan tingkah laku itu tidak dapat dijelaskan atau dasar kecendrungan respon pembawaan, kematangan atau keadaan-keadaan sesaat seseorang.

Metode inqury adalah cara penyampaian bahan pengajaran dengan memberi kesempatan kepada siswa untuk belajar mengembangkan potensi intelektualnya dalam jalinan kegiatan yang disusunnya sendiri untuk menemukan sesuatu sebagai jawaban yang meyakinkan terhadap permasalahan yang dihadapkan kepadanya melalui proses pelacakan data dan informasi serta pemikiran yang logis, kritis dan sistematis. (Slameto, 2003: 116)

Metode Inquiry istilah dalam Bahasa inggris, ini merupakan suatu teknik atau cara yang digunakan guru untuk mengajar di depan kelas. Adapun pelaksanaannya sebagai berikut: guru membagi tugas meneliti suatu masalah ke kelas. Siswa di bagi menjadi kelompok, dan masing-masing kelompok mendapat tugas tertentu yang harus dikerjakan. (Roestiyah, 2008: 75) Metode ini berasal dari Johhn Dewey, maksud utama metode ini adalah memberikan latihan kepada siswa dalam berfikir. Metode ini dapat menghindarkan untuk membuat kesimpulan tergesa-gesa, menimbang-nimbang kemungkinan pemecahan, dan menangguhkan pengambilan keputusan sampai terdapat bukti-bukti yang cukup. (Muhaimin, 2005: 88) Metode inqury ini merupakan suatu metode yang merangsang siswa untuk berfikir, menganalisa suatu persoalan sehingga menemukan pemecahannya. Dalam Bahasa inggrisnya disebut problem solving method. Metode ini membina kecakapan untuk melihat alasan-alasan yang tepat dari suatu persoalan, sehingga pada akhirnya dapat ditemukan bagaimana cara penyelesaiannya. Metode inipun adalah metode yang membina siswa untuk dapat berfikir ilmiah, yaitu cara berfikir yang mengikuti jenjang-jenjang tertentu di alam penyelesaiannya. Kemampuan untuk memperoleh tilikan dapat dilatih dan dikembangkan dengan metode mengajar semacam ini. (Djajadisastra, 2001: 19) Metode inquiry juga dikembangkan oleh Suchman untuk mengajar siswa memahami proses penelitian. (Joyce and Weil, 2011: 56) Suchman tertank untuk membantu siswa melakukan penelitian secara mandiri dan disiplin. Hal ini didasarkan pada pemikiran bahwa anak-anak selalu memiliki rasa ingin tau. Suchman menginginkan siswa mempertanyakan mengapa suatu peritiwa terjadi dan menelitinya dengan cara mengumpulkan dan mengolah data secara logis. Dengan demikian maka metode inquiry 
akan memperkuat dorongan alami untuk melakukan ekplorasi dengan semangat besar dan dengan penuh kesungguhan. Dalam penelitian ini model inquiry yang dipakai adalah inquiry yang dikembangkan oleh Suchman. Model inquiry ini dimulai dengan menyajikan situasi yang penuh dengan pertanyaan. Setelah situasi tersebut disajikan pada siswa, kemudian para siswa diberitahu bahwa mereka perlu mengupas beberapa aspek dan situasi itu, misalnya mengenai sifat dan defenisi. Pada saat seperti ini siswa diperbolehkan untuk bertanya itu dijawab oleh guru hanya dengan kata "ya" atau "tidak". Langkah terakhir siswa diharapkan dapat menyimpulkan sendiri jawaban masalah yang diajukan

Media berasal dari kata "Medium", yang berasal dari Bahasa latin "Medium" yang berarti "tengah" atau "sedang". Pengertian media ini mengarah pada suatu yang menjadi penghantar untuk meneruskan suatu informasi dari sumber informasi kepada penerima informasi.

Media merupakan suatu wadah atau sarana dalam menyampaikan suatu informasi dari pengirim kepada penerima. Media adalah segala bentuk dan saluran yang dapat digunakan dalam suatu proses penyajian informasi.

Banyak batasan-batasan yang diberikan dalam memberikan pengertian media. Asosiasi Teknologi dan Komunikasi Pendidikan atau Association of Education and Communication Technology (AECT) membatasi media sebagai saluran yang digunakan orang untuk menyalurkan pesan atau informasi. Batasan yang lain juga diberikan oleh Asosiasi Pendidikan Nasional atau Education Association (NEA) yang membatasi media meruapakan bentuk-bentuk komunikasi baik tercetak maupun Audiovisual serta peralatannya serta media hendaknya dapat dimanupulasi, dapat didengar, dilihat dan dibaca.

Salah satu media Audio-Visual adalah media VCD pembelajaran menurut Brown adalah suatu media pada program distribusi atau produksi untuk program master yang dibuat dalam bentuk file atau video tape dan dipindahkan atau ditransfer pada disc atau potongan plastik melalui proses yang tepat, yang dibentuk seperti piringan hitam.

Selain itu Heinich, juga mengemukakan pengertian VCD adalah sebuah disc plastik yang digunakan untuk merekam suara, gambar, dan bahkan simbol atau lambang, dan juga suara dan gambar tersebut bisa ditayangkan atau ditampilkan kembali melalui VCD player dan monitor televisi. Begitu juga dengan Locatis mengemukakan pengertian VCD adalah suatu benda yang diformat untuk program televisi, yang fungsinya bisa merekam dan menampilkan informasi dalam bentuk audio visual.

Dari beberapa pendapat tersebut dapat disimpulkan bahwa media VCD pembelajaran adalah media berbentuk piringan lengkap audio visual yang berisikan materi pelajaran serta dimasuki dengan suara narator yang berguna untuk menjelaskan objek yang telah divisualkan, biasanya mempunyai diameter 12 $\mathrm{cm}$. Sehingga manfaat VCD pembelajaran adalah sangat membantu guru dalam penyampaian ide-ide atau gagasan mata pelajaran yang diinformasikan kepada siswa dan antara dengan siswa memliki persamaan persepsi.

Dalam proses belajar mengajar metode dan media pengajaran sangat berpengaruh sekali terhadap prestasi belajar siswa, terutama pada mata pelajaran Indonesia, dimana kedua aspek ini saling berkaitan. Pemilihan salah satu metode mengajar tertentu akan mempengaruhi jenis media pengajaran yang sesuai, meskipun masih ada berbagai aspek lain harus diperhatikan dalam memilih media, antara lain tujuan pengajaran, jenis tugas, dan respon yang diharapkan siswa kuasai setelah pengajaran berlangsung, dan konteks pembelajaran termasuk karakteristik siswa. Meskipun demikian, dapat dikatakan bahwa salah satu fungsi utama media pengajaran adalah sebagai alat bantu mengajar yang turut mempengaruhi iklim, kondisi, dan lingkungan belajar yang ditata dan diciptakan oleh guru.

Media pendidikan atau alat peraga memegang peranan penting untuk menciptakan proses belajar mengajar yang efektif dan efisien, karena dengan media ini 
bahan pelajaran akan mudah diserap oleh siswa.

Pada mulanya media pendidikan hanyalah sebagai alat bantu dalam kegiatan belajar mengajar, tetapi sekarang sudah menjadi bagian yang integral dalam proses belajar mengajar. Yaitu sebagai sarana yang dapat menyampaikan informasi dalam rangka mendorong motivasi belajar siswa, sehingga dengan demikian diharapkan apa yang dipelajari siswa sudah mudah dimengerti dan dipahami.

Menurut media pengajaran dapat mempertinggi proses belajar siswa dalam pengajaran yang pada gilirannya diharapkan dapat mempertinggi hasil belajar yang dicapai. Senada dengan itu, Sudarman Danim menyatakan hasil penelitian secara nyata membuktikan bahwa penggunaan alat bantu sangat membantu proses belajar mengajar di kelas, terutama meningkatkan prestasi belajar siswa.

Terus menyatakan bahwasanya media pengajaran paling besar pengaruhnya bagi indera dan lebih cepat menjamin pemahaman orang yang mendengarkan saja tidaklah sama tingkat pemahamannya dan lamanya bertahan apa yang dipahaminya dibandingkan dengan mereka yang melihat, atau melihat dan mendengar.

Senada dengan itu, Ibrahim juga menyatakan bahwa media pengajaran membawa dan membangkitkan rasa senang dan gembira bagi siswa-siswa dan memperbarui semangat mereka membantu memantapkan pengetahuan pada benak siswa serta menghidupkan pelajaran.

\section{METODE PENELITIAN}

Jenis penelitian ini adalah penelitian deskriptif kuantitatif dalam bentuk eksperimen yaitu penelitian yang bersifat langsung dilapangan untuk mengetahui perbandingan anatara variabel $\mathrm{X}$ dan variabel Y. Penelitian ini merupakan penelitian yang bersifat Kuantitatif yaitu hasil penelitian diperoleh dalam bentuk angka. Berdasarkan (Sugiyono, $2007: 8$ ) mengemukakan bahwa penelitian kuantitatif adalah penelitian yang menyajikan datanya berupa angka-angka dan menggunakan analisa statistik yang bertujuan untuk menunjukkan hubungan antara variabel, menguji teori dan mencari generalisasi yang mempunyai nilai prediksi.

Lokasi penelitian ini dilakukan di MTs Negeri Lappariaja yang tepatnya di Kelurahan Patangkai Kecamatan Lappariaja Kabupaten Bone, Waktu penelitian selama 2 bulan yaitu mulai bulan April sampai dengan bulan Juni 202.

Variabel penelitian ini terdiri dari dua macam variabel yaitu variabel bebas dan variabel terikat. Variabel bebas yang dimaksud adalah hasil belajar Bahasa Indonesia yang menggunakan metode inquiry dengan media VCD yang digunakan dalam mata pelajaran Bahasa Indonesia dan variabel terikat yang dimaksud adalah hasil belajar Bahasa Indonesia yang tidak menggunakan metode inquiry dengan media VCD.

Untuk mendapatkan persamaan persepsi terhadap variabel yang dikaji, maka perlu dikemukakan definisi operasioanl secara jelas yaitu :

1. Metode inquiri adalah cara menyampaikan materi bahan ajar dengan memberikan kesempatan kepada siswa untuk belajar mengembangkan potensi intelektual di dalam kegiatan yang disusun sendiri untuk menemukan sesuatu sebagai jawaban yang meyakinkan terhadap permasalahan yang dihadapkan. Metode inquiri ini merupakan suatu teknik yang digunakan guru untuk mengajar didepan kelas. Guru membagi tugas kelompok dan masing masing kelompok mendapat tugas tertentu yang harus dikerjakan.

2. Media VCD adalah media yang mengarah pada sesuatu yang menjadi pengantar untuk meneruskan suatu informasi dari sumber informasi kepaada penerima informasi. Media sebagai saluran yang digunakan orang untuk menyalurkan peran atau informasi dalam bentuk VCD. Sedangkan media VCV adalah pembelajaran dalam bentuk piringan plastik untuk merekam suara, gambar, simbol yang dapat ditayangkan 
atau ditampilkan melalui VCV dan Monitor.

3. Hasil belajar didefinisikan sebagai hasil yang dicapai setelah melakukan kegiatan belajar yang merupakan kemampuan nyata yang dapat diukur langsung dengan menggunakan tes hasil belajar

Mengingat bahwa jumlah populasi terbatas dengan jumlah 43 orang siswa dibawah 100 orang, maka semua populasi di jadikan sampel untuk mengikuti tes dalam mata pelajaran Bahasa Indonesia. Dalam penelitian ini yang dijadikan sampel yaitu kelas VII A sebagai kelas kelompok eksperimen dan kelas VII B sebagai kelas kelompok kontrol. Untuk lebih jelasnya dapat dilihat pada tabel berikut ini :

Tabel 3.2. Sampel Penelitian

\begin{tabular}{|l|l|l|l|}
\hline No & Kelas & Kelompok & Jumlah \\
\hline & & Eksperimen & Kontrol \\
\hline 1 & VII A & 21 & - \\
\hline 2 & VII B & - & 22 \\
\hline Jumlah & 21 & 22 & 43 \\
\hline
\end{tabular}

Sumber: Data dari tabel 3.1 tahun pelajaran

Teknik analisis data yang diigunakan dalam penelitian ini adalah teknik analisis statistik deskriptif dan statistik inferensial. Analisis statistik deskriptif dalam penelitian ini menggunakan perosentase.

\section{HASIL DAN PEMBAHASAN}

Hasil kuantitatif adalah hasil penelitian yang menggambarkan bagaimana perbedaan hasil belajar Bahasa Indonesia yang menggunakan metode inquiry dengan media VCD dan tidak menggunakan metode inquiry dengan media VCD yang dinyatakan dalam bentuk angka, sedangkan hasil kualitatif adalah hasil penelitian yang dirumuskan dalam bentuk pernyataan dan pembuktian hipotesis

Berdasarkan data diketahui bahwa skor tertinggi yang capai oleh siswa adalah 19 dari skor maksimum yang akan dicapai 20. Skor terendah yang dicapai oleh siswa adalah 12 dari skor minimum yang mungkin dicapai oleh siswa yaitu 0. Rata-rata skor yang diperoleh siswa yaitu 16,7 dengan standar deviasi 2,24.

Berdasarkan data pada tabel 4.2 tersebut diketahui bahwa dari 21 orang siswa yang dijadikan sampel penelitian, terdapat 14 orang siswa $(66,6 \%)$ memperoleh hasil belajar Bahasa Indonesia yang dikategorikan sangat tinggi, 6 orang siswa $(28,6 \%)$ memperoleh hasil belajar Bahasa yang dikategorikan tinggi, 1 orang siswa $(4,8 \%)$ memperoleh hasil belajar yang dikategorikan sedang dan tidak ada siswa yang memperoleh hasil belajar yang dikategorikan rendah maupun sangat rendah.

Berdasarkan data pada tabel 4.2 maka diketahui bahwa hasil belajar siswa Bahasa Indonesia yang menggunakan metode inquiry dengan VCD dapat dikategorikan sangat tinggi, hal ini terlihat pada rata-rata skor yang diperoleh siswa dengan frekuensi 14 orang atau $66 \%$ yang berada pada interval $17-20$

Berdasarkan data pada tabel 4.3 di atas maka dapat diketahui bahwa skor tertinggi yang dicapai oleh siswa 17 dari skor maksimum yang akan dicapai 20. Skor terendah yang dicapai oleh siswa 8 dari skor minimum yang mungkin dicapai 0 . Rata-rata skor perolehan siswa yaitu 13,8 dengan standar deviasi 2,34. Data pada tabel 4.3

Berdasarkan data pada tabel 4.4, maka diketahui bahwa hasil belajar Bahasa Indonesia siswa kelas VII MTs. Negeri Lappariaja Kecamatan lappariaja Kabupaten Bone yang tidak menggunakan metode inquiry dengan VCD secara umum dapat dikategorikan tinggi, hal ini terlihat pada ratarata skor yang diperoleh 15 0rang, atau 68,1\% yang berada pada interval $13-16$

Secara deskriptif hasil penelitian ini menunjukan bahwa hasil belajar Bahasa Indonesia siswa kelas VII MTs. Negeri Lappariaja Kecamatan lappariaja Kabupaten Bone yang menerapkan hasil belajar Bahasa Indonesia yang menggunakan metode inquiry dengan media VCD secara umum dikategorikan sangat tinggi, hal ini terlihat pada rata-rata skor yang diperoleh siswa yaitu $66,6 \%$ yang berada frekuensi 14 orang pada interval $17-20$ dan yang menerapkan metode tidak menggunakan metode inquiry dengan media VCD secara umum dikategorikan tinggi, hal in terlihat pada rata-rata skor yang diperoleh siswa yaitu $68,1 \%$ yang berada pada interval $13-16$. 
Selain itu kelompok siswa yang menerapkan yang menggunakan metode inquiry dengan media VCD terdapat 14 siswa yang mendapatkan hasil belajar pada kategori sangat tinggi dan tidak ada siswa yang memperoleh hasil belajar pada kategori rendah, namun pada kelompok siswa yang tidak menerapkan metode inquiry dengan media VCD terdapat 1 siswa yang mendapatkan hasil belajar pada kategori sangat tinggi dan masih ada 1 siswa yang hasil belajarnya berada pada taraf kategori rendah.

Hasil analisis data secara deskriptif pada penelitian ini di dukung oleh hasil analisis data secara inferensial yaitu dengan nilai thit $=4,20$. Dan pada taraf

nyata $\alpha=0,05$ dangan $\mathrm{dk}=21+22-2$ $=41$, maka diperoleh pada ttab $=2,020$ Ternyata thit $>\operatorname{ttab}=4,20>2,020$ dan taraf nyata $\alpha=0,01$ atau $1 \%$ adalah Ternyata thit $>$ ttab $=4,20>2,701$ hal ini berarti H0 ditolak sedangkan $\mathrm{H} 1$ diterima, dengan demikian hipotesis penelitian diterima, maka hasil belajar siswa kelas VII MTs. Negeri Lappariaja Kecamatan lappariaja Kabupaten Bone yang menggunakan metode inquiry dengan media VCD dengan tidak menggunakan metode inquiry dengan media VCD ada perbedaan.

\section{KESIMPULAN}

Berdasarkan hasil analisa data dan pembahasan yang telah dilakukan pada bab sebelumnya, maka hasil penelitian ini dapat disimpulkan bahwa :

Hasil belajar Bahasa Indonesia siswa siswa kelas VII MTs. Negeri Lappariaja Kecamatan lappariaja Kabupaten Bone yang menerapkan hasil belajar Bahasa Indonesia yang menggunakan metode inquiry dengan media VCD berada pada kategori sangat tinggi yaitu rata-rata 16,7 sedangkan yang tidak menggunakan metode inquiry dengan media VCD berada pada kategori tinggi dengan skor 13,8

Hasil belajar siswa yang menerapkan metode hasil belajar Bahasa Indonesia yang menggunakan metode inquiry dengan media VCD dan tidak menggunakan metode inquiry dengan media VCD, ada perbedaan yaitu nilai t hitung 4,20 pada taraf signifikan $5 \%$ pada $t$ tabel $=2,020$

\section{DAFTAR PUSTAKA}

Abidin, 2008. Kesulitan belajar dan Pembelajaran. Jakarta: Rineka Cipta

Arikunto, 2005. Manajemen Penelitian. Rineka Cipta Jakarta.

Brown, 2001. Metode Penelitian dalam Teori dan Praktek . Jakarta : Grasindo

Chield, 2004. Pembelajaran Kooperative Scriptes. Jakarta : Grasindo

D.F. Ausuble, 2000. Evaluasi Belajar Dalam Pendidikan, Jakarta : Rineka Cipta

Danim, 2002. Pengantar Studi Penelitian Kebijakan. Jakarta : Bumi Aksara

Djajadisatra, 2001. Metode-Metode Mengajar, Angkasa : Bandung

Djamarah, 2002. Psikologi Belajar Jakarta: Rineka Cipta

Gagne, 2000. Cara Belajar Yang Efisien, Yogyakarta : UGM Press

Hamalik, 2007. Evaluasi Belajar Mengajar. Bnadung : Tarsito

Heinich dkk, 2003. Instructional Media. New York : Memillan Publishong

Hilgard dan Bower, 2002. Pendekatan dalam Proses Belajar Mengajar, Jakarta : Bina Aksara.

Ibrahim, 2004. Model-Model Pembelajaran Strategi Belajar, Bandung : Refika Aditama

John Dawey, 2000. Democracy and Education Newyork : Macmillan

Joice and Well, 2011. Model Of Teaching New Jersey : Prentice Hal. Inc

Kem dan Daytori, 2003. Proses Belajar Mengajar, Jakarta : Balai Pustaka

Lislie J. Brigs, 2005. Dasar-Dasar Pendidikan, Jakarta : Bumi Aksara

Locatis, 2004. Model Pembelajaran Kooperatif, Bandung : Remaja Karya 